\title{
Use of Lactobacillus from Pulque in Sourdough
}

\author{
A. Quintero Lira', M. G. Alvarado-Resendiz ${ }^{1}$, S. Soto Simental'2, J. Piloni Martini'2, \\ Ma. I. Reyes-Santamaria ${ }^{1}$, N. Guemes-Vera ${ }^{1 *}$ \\ ${ }^{1}$ Área Académica de Ingeniería Agroindustrial, Instituto de Ciencias Agropecuarias, Universidad Autónoma del \\ Estado de Hidalgo, Tulancingo Hidalgo, México \\ ${ }^{2}$ Area Academica de Medicina Veterinaria y Zootecnia, Instituto de Ciencias Agropecuarias, Universidad \\ Autónoma del Estado de Hidalgo, Tulancingo Hidalgo, México \\ Email: ${ }^{*}$ jigv2002@yahoo.com.mx
}

Received 7 June 2014; revised 10 July 2014; accepted 12 August 2014

Copyright (C) 2014 by authors and Scientific Research Publishing Inc.

This work is licensed under the Creative Commons Attribution International License (CC BY).

http://creativecommons.org/licenses/by/4.0/

(c) (i) Open Access

\section{Abstract}

The purpose of this study is to determine whether there are significant differences in the use of lactic acid bacteria isolated from pulque dough Lactobacillus plantarum and Lactobacillus paracasei ssp. paracasei alone and combined with baker's yeast in the properties of the dough and the finished product. The best bacteria were selected using growth kinetics and statistical analysis with the Sigma Plot 11 program. Physical-chemical tests $\mathrm{pH}$ \% \% acidity of the dough. Physical tests, texture profile analysis, image analysis of the crumb structure and sensory analysis were performed on the finished product. The results show that the most suitable LAB to ferment dough in 5 hours is Lactobacillus paracasei ssp. paracasei which reduce $\mathrm{pH}$ and increase acidity more quickly. The combination of Lactobacillus paracasei ssp. paracasei plus baker's yeast presents better quality attributes in terms of texture, flavor and appearance for the final consumer.

\section{Keywords}

Lactic Acid Bacteria, Bread, Texture Profile Analysis, Pulque Bread, Dough Pulque

\section{Introduction}

The sourdough in wheat bread production clearly improves dough properties, bread texture and flavor, delays the staling process and prevents bread from mould and bacterial spoilage [1] [2]. These benefits result from a common trend of sourdough fermentations are the unique symbiosis of certain hetero- and homo-fermentative

"Corresponding author. 
lactic acid bacteria whit certain yeasts. Lactobacillus sanfranciscensis, L. brevis and L. plantarum are the most frequently isolated lactic acid bacteria, while Saccharomyces cerevisiae is the yeast most frequently present [1]-[4]. In spontaneous sourdough fermentations, it is likely that apart from the dominant lactic acid bacteria and yeast species that are isolated in numbers suggest a significant contribution to the fermentation, a secondary microbiota exists atm lower numbers. This secondary microbiota includes lactic acid bacteria species such as $L$. alimentarius, L. acidophilus, L. fructivorans, L. fermentum, L. reuteri and L. pontis [3] [4] and yeast species such as S. exiguous, Candida krusei and C. milleri [5].

Within Mexican gastronomy, the breadmaking industry is not only a source of employment but part of artisanal, business and cultural development for Mexican people. There are many natural products that can serve as raw material for breadmaking, among them pulque, a traditional Mexican drink dating back to the pre-Hispanic era. Pulque is rich in carbohydrates and microorganisms such as lactic acid bacteria, acetic acids and yeasts. These bacteria ferment the sugars forming acetic acid, ethanol, lactic acid and $\mathrm{CO}_{2}$ depending on the species, and contribute to food biopreservation, improve sensory attributes such as taste, aroma and texture, and increase nutritional value. Yeasts help the formation of gas by fermenting sugar to ethanol and $\mathrm{CO}_{2}$ [6]. Pulque bread can contain alcohol and lactic acid produced by the inoculum of pulque which may inhibit undesirable bacteria. The bread is made with sourdough [6] which is a mixed culture of lactic acid bacteria and yeast. The introduction of new methods to improve bread creates new challenges for obtaining a good quality product given the wide selection of additives, such as enzymes, emulsifiers, antioxidants and preservatives, which unquestionably improve, above all, the flavor, texture and shelf life of bread. Nevertheless, the majority of these are made with chemical products, going against the current consumer trend to prefer natural foods without chemical additives. Using microorganisms from natural products may be effective in improving the characteristics of bread. In this work we determined the physical-chemical characteristics of bread made with lactic acid bacteria of the genusLactobacillus isolated from sourdough pulque.

\section{Materials and Methods}

\subsection{Materials}

Lactic acid bacteria isolated from the pulque's doughs. Flour bulk silver leaf (Elizondo), fat (La Gloria), standard sugar (Golden Hills), egg (Bachoco), yeast (tradipan), milk powder (Nido), salt (Fina), pulque (obtained from Singuilucan region in the state of Hidalgo, Mexico) and distilled water and sterile saline.

Lactic Acid Bacteria. Lactic acid bacteria studied were isolated and identified by the technique API 50 CHL, colonial morphology (color, size, type, edge, elevation, reflected light, transmitted light) and cellular (Gram staining and catalase) sourdough with pulque in the Microbiology Laboratory Sciences Research Center and Food Technology of ICAp-UAEH, which they were encoded as LB1 to LB10 and they kept in MRS agar plus $10 \%$ glycerol according of method of Sanchez [7].

\subsection{Methods}

Flour analysis. Moisture and total solids determination was using 44-19 method [8], ash by the method 14-006 [9] and protein by the method 20 - 57 [9].

Pulque's doughs preparation. Determination of the growth kinetics of Lactobacillus strains: from BAL strains preserved, were activated in MRS agar petri dishes (DIFCO) cross-streak, were subsequently incubated at $37^{\circ} \mathrm{C}$ for 48 hours [10]. The selection of BAL for the dough fermented was based on the production of $\mathrm{CO}_{2}$, BAL growth: once the growth of each of the strains selected on the basis of the results obtained (BL2, BL6 and BL7), will take a colony and inoculated into Erlenmeyer flask with $99 \mathrm{~mL}$ of MRS broth which was incubated at $37^{\circ} \mathrm{C}$ for 48 hours (performed in triplicate), which was used to incubate with $1 \mathrm{~mL}$ for each of the 33 test tubes, (3 tubes 3 each control and fermentation time) containing $9 \mathrm{~mL}$ of MRS broth which corresponded to the following times $\left(0,30,60,90,120,150,180,210,240,270\right.$ and 300 minutes). These tubes were incubated at $37^{\circ} \mathrm{C}$, after, each time decimal dilutions from $10^{-1}$ to $10^{-6}$. In MRS agar petri dishes were placed $50 \mu \mathrm{l}$ of the last three dilutions using the scanning technique in plate. Preparation of inoculum: culturing the BAL (BL2, BL6 and BL7) were inoculated at $1 \% \mathrm{~V} / \mathrm{V}$ in Erlenmeyer flasks containing $99 \mathrm{~mL}$ of MRS broth, and incubated for $24 \mathrm{~h}$ at $37^{\circ} \mathrm{C}$. Biomass was obtained by centrifugation ( $5000 \mathrm{rpm}, 4^{\circ} \mathrm{C}$ for $15 \mathrm{~min}$ ). Biomass was resuspended in $50 \mathrm{~mL}$ sterile saline (0.9\%), cell concentration containing $108 \mathrm{CFU} / \mathrm{mL}$. It was added directly to the dough [11]. 
Fermentation of pulque's dough. $110 \mathrm{~g}$ dough were prepared with each of the selected bacteria (LB2, LB6 and LB7), 11 samples were obtained $10 \mathrm{~g}$ of dough portions each corresponding to each fermentation time $(0,30,60$, 90, 120, 150, 180, 210, 240, 270 and $300 \mathrm{~min}$ ), then incubated at $37^{\circ} \mathrm{C}$. In a sterile bag (Nasco Whirl-Pak) insertion of a portion of dough $10 \mathrm{~g}$ plus $100 \mathrm{~mL}$ of sterile distilled water, the mixture was ground in a Stomacher (40 recirculator, Sward) at $250 \mathrm{rpm}$ for $90 \mathrm{~s}$. Subsequent dilutions were made from $10^{-1}$ to $10^{-7}$. Then plated on MRS agar petri dishes, $50 \mu \mathrm{l}$ of the last three dilutions using the plate scanning technique for $24 \mathrm{~h}$. Analytical determination of $\mathrm{pH}$ was using $10 \mathrm{~g}$ dough and $100 \mathrm{~mL}$ of distilled water were ground with a food processor (Brand Taurus) in a beaker for $3 \mathrm{~min}$ at speed 1 processor. After potentiometer brand electrode (Oakton SN) was submerged and the values were recorded. It made in triplicate [9]. Analytical determination of acidity: according $10 \mathrm{~g}$ of sample put up and dissolved in $50 \mathrm{~mL}$ of distilled water. It was added $2 \mathrm{~mL}$ of a solution of $1 \%$ phenolphthalein. The solution was titrated with $0.1 \mathrm{~N}$ sodium hydroxide until it formed a transparent turns from pink. It made in triplicate.

Texture Profile Analysis with Peltier Control Unit for the doughs. 25 g samples of $3 \times 3 \mathrm{~cm}$ in diameter and height were compressed on a texture analyzer TAHDi (Texture Technologies, New York, USA/Stable Microsystems, Surrey, UK) and a control unit Peltier with a load cell of $50 \mathrm{~kg}$ and a cylindrical probe Delrin half inch at a speed of $1 \mathrm{~mm} / \mathrm{s}$ by compressing the dough in two cycles to $50 \%$ of its original height with a waiting period of $5 \mathrm{~s}$ between each. Compression is carried out every $30 \mathrm{~m}$ for $5 \mathrm{~h}$. To obtain the following parameters after APT: hardness, elasticity, adhesiveness and cohesiveness, the analysis made in triplicate.

Bread Analysis. A series of bread analyses was performed with three loaves at day 0, after $2 \mathrm{~h}$ of cooling, before packaging. The crust and crumb, were determined put on a whole loaf, remove the crust and weigh it, the result is subtracted from the initial weight of the bread crumbs give the amount that should be related to 100 . The coefficient of elevation was determined the width/height were measured with a vernier, at the center slice of bread [12]. Loaf weight and volume (rapeseed displacement method) were calculated. Images of the bread were obtained three slices of bread for each formulation of $1 \mathrm{~cm}$ thick on a scanner HP Officejet J5700 (tiff image format), with a resolution of $600 \mathrm{pp}$ and analyzed by ImageJ 1.45 program (National Institutes of Health, Bethesda, MD, USA). Texture profile analysis (TPA) of bread: Loaves of $25 \mathrm{~g}$ of $3 \times 3 \mathrm{~cm}$ in diameter and height were compressed on a TAHDi texture analyzer (Texture Technologies, New York, USA/Stable Microsystems, Surrey, UK), with a load cell of $50 \mathrm{~kg}$ and a probe P25/L perspex cylinder $25 \mathrm{~mm}$ at a speed of $1 \mathrm{~mm} / \mathrm{s} \mathrm{by} \mathrm{com-}$ pressing the doughs in two cycles to $50 \%$ of its original height with a waiting period of $5 \mathrm{~s}$ between each. Obtain the following parameters APT: hardness, elasticity, resilience and cohesiveness, the analysis was performed in triplicate. The color was analyzed according Anzaldúa [13]. The sensory analysis was performed to 35 consumers, according to Anzaldúa [13].

Statistical Analysis. The statistical analysis was a completely randomized design with a statistical package Sigma Plot 11. An analysis of variance (ANOVA) and mean comparisons by the Tukey method $(\mathrm{P} \leq 0.05)$. The Table 1 shows the formulations used for the manufacture of bread's pulque whit the yeast + BAL 2, 6 and 7 .

Table 1. Formulations used for the manufacture of breads and doughs with pulque, and yeast inoculum.

\begin{tabular}{cccc}
\hline Ingredients (\%) & Pulque's dough & LAB 2, 6, 7 + dough & LAB 2, 6, 7 + yeast \\
\hline Flour & 100 & 100 & 100 \\
Sugar & 15.6 & 15.6 & 15.6 \\
Salt & 1.2 & 1.2 & 1.2 \\
Fat & 25.0 & 25.0 & 25.0 \\
Milkpowder & 5.0 & 5.0 & 5.0 \\
Egg & 20.5 & 20.5 & 20.5 \\
Water & 20.0 & 20.0 & 20.0 \\
Pulque & 15.0 & 0.0 & 0.0 \\
Yeast & 0.0 & 0.0 & 0.2 \\
LAB 2, 6, 7 & 0.0 & 15.0 & 15.0 \\
\hline
\end{tabular}

The percentage is based on a function of the flour. LB7 = Lactobacillus paracasei ssp. paracasei; LB6 = Lactobacillus paracasei ssp. paracasei; LB2 = Lactobacillus paracasei ssp. paracasei. 


\section{Results and Discussion}

\subsection{Proximate Analysis of Wheat Flour}

According to the results obtained from this analysis the flour was found to be Grade I for bread making, maximum moisture $14.0 \%$, minimum protein $9.5 \%$ and maximum ash $0.55 \%$ giving an excellent baking quality due to the protein content [14].

\subsection{LAB Growth Kinetics}

From the microscopic observations made using Gram stain, catalase testing, API testing and colonial morphology, the bacteria isolated from dough fermented with pulque were identified as reported in Table 2, where 50\% were Lactobacillus paracasei ssp. paracasei and the remaining 50\% were Lactobacillus plantarum, from which we selected LB2, LB6 and LB7 (Lactobacillus paracasei ssp. paracasei) since they reported the highest growth rate and significant differences between them $(\alpha=0.05)$.

It can be seen from the behavior of the LAB in the dough that due to their rapid growth and adaptability to the medium, the results are favorable.

\subsection{The Acidification Properties during Pulque's Dough Fermentation}

In the Figure 1, it showed the effect of the LAB starter on $\mathrm{pH}$ values was monitored over 300 min pulque's dough fermentation and was compared with an uniculated Saccharomyces cereviceae dough prepared under the same conditions. As expected the $\mathrm{pH}$ value nearly constant (5.2 to 4.7). During the same period the acidity increase of $0.33 \%$ to $0.49 \% \mathrm{v} / \mathrm{v}$ lactic acid during the fermentation of $5 \mathrm{~h}$. Start yeast dough with $\mathrm{pH} 6.32$ and only get 6.22 of $5 \mathrm{~h}$, the acidity was to $0.27 \%-0.32 \% \mathrm{v} / \mathrm{v}$ lactic acid. Doughs were inoculated only with Lactobacillus a final $\mathrm{pH}$ of 4.67 , for LB2, 4.91 y 4.51 to LB6 and LB7 respectively, the acidity was between $0.43 \%$ to $0.53 \%, 0.37 \%$ to $0.52 \%, 0.32 \%$ to $0.44 \% \mathrm{v} / \mathrm{v}$ lactic acid. The acidity of the doughs with Lactobacillus sp, showed to the time $6 \mathrm{~h}$ a pH of 5.7 and acidity was $0.18 \% \mathrm{v} / \mathrm{v}$ lactic acid, in this investigation the 3 strains of Lactobacillus paracasei ssp. paracasei 2, 6 and 7 decreased the $\mathrm{pH}$ and the acidity was higher than previously reported [15]. The $\mathrm{pH}$ differed depending on the fermentation temperature and LAB concentration, whereas the acidity was greatly affected by the fermentation temperature [16]. The fermentation temperature and time affected the volume of the dough, although there was no significant difference. The volume of the sourdough rapidly increased early and maintained a constant volume until the end of the fermentation process.

Lactobacillus doughs inoculated more with commercial yeast resulted for LB2 + yeast a final pH of 5.8 and acidity of $0.32 \% \mathrm{v} / \mathrm{v}$ lactic acid, for LB5 and LB7 + yeast the $\mathrm{pH}$ was of 6.22 and 6.24 respectively, and the acidity of $0.32 \% \mathrm{v} / \mathrm{v}$ lactic acid for the 2 . The dough acid fermentation whit $L b$. sanfranciscencis and S. cerevisiae reached within $24 \mathrm{~h} \mathrm{pH}$ of 3.96 and acidity of $0.85 \%$, the fermentation temperature of $25^{\circ} \mathrm{C}$, yeast growth was most active, but as the temperature decreased, the number of yeast cells decreased slowly, the causing fermentation activity to also decrease [16]. According to the results obtained and consulted bibliography the best

Table 2. Identification of the lactobacillus bacterias isolated from dough fermented with pulque.

\begin{tabular}{cr}
\hline Bacteria code & Bacteria identified \\
\hline LB1 & Lactobacillus paracasei ssp. paracasei \\
LB2 & Lactobacillus paracasei ssp. paracasei \\
LB3 & Lactobacillus paracasei ssp. paracasei \\
LB4 & Lactobacillus plantarum \\
LB5 & Lactobacillus plantarum \\
LB6 & Lactobacillus paracasei ssp. paracasei \\
LB7 & Lactobacillus paracasei ssp. paracasei \\
LB8 & Lactobacillus plantarum \\
LB9 & Lactobacillus plantarum \\
LB10 & Lactobacillus plantarum \\
\hline
\end{tabular}



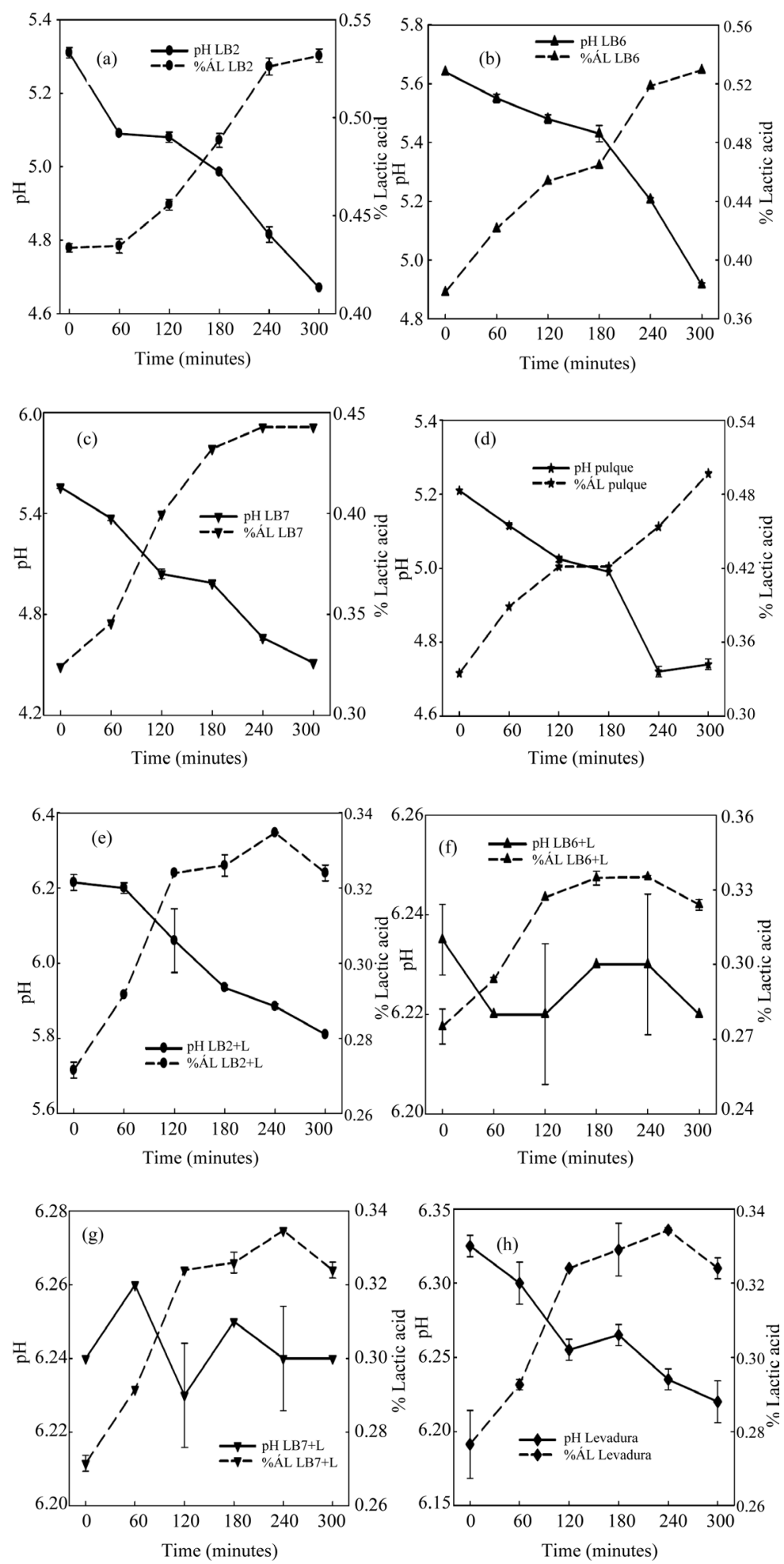

Figure 1. (a) pH and \% lactic acid of dough with LB2; (b) pH and \% lactic acid of dough with LB6; (c) pH and \% lactic acid of dough with LB7; (d) pH and \% lactic acid of dough with pulque; (e) $\mathrm{pH}$ and \% lactic acid of dough with LB2 + L; (f) pH and \% lactic acid of dough with LB6 + L; (g) pH and \% lactic acid of dough with LB7 + L; and (h) $\mathrm{pH}$ and \% lactic acid of dough with yeast. 
results from the fermentation of the doughs was the LB7 + yeast mixture.

\subsection{Behavior of LAB in Dough}

Figure 1 showed that the LB2 remained constant with a count of $8.86 \mathrm{Log}$ UFC/mL until minute 150 when it presented a decrease in growth. LB6 and LB7 showed a growth decrease from minute 60 reaching the end of fermentation with a count of 8.65 and $8.35 \mathrm{Log}$ UFC/mL respectively.

The fermentation of dough has beneficial effects since it prolongs shelf life, increases volume, delays hardening, and improves the flavor and nutritional value of the bread [17] [18].

In determining the lift coefficient (Table 3) its importance can be said to lie in the quality of the bread and it being well-made since there are no proteolytic bacteria that can impair the retention of gases that are essential for the rising (volume) of the dough [14]. The breads made solely with Lactobacillus presented a higher lift coefficient indicating the presence of proteolytic bacteria which inhibited the increase in volume of the bread. In contrast, the breads made with baker's yeast and Lactobacillus did present a good lift coefficient; here the leavening agents were more active achieving a better "volume" of bread. The importance of the volume is that it is directly related to the volume of the crumb pores, and it also indicates that the bread is well made and of good quality. As can be seen, LB7 was of the poorest quality with an index of 0.52 , followed by all the breads inoculated solely with lactobacilli and pulque which had an index of $0.45-0.46$ and were also of poor quality in terms of volume. The breads inoculated with lactobacilli and baker's yeast had an apparent density index of $0.21-0.22$, indicating a good quality bread since it varies between $(0.20-0.22)$. In the percentages of crust and crumb we find that the breads with lactobacilli have $81.09 \%-83.03 \%$ crumb and $16.97 \%-18.91 \%$ crust which tells us there is a slight alteration since well-made bread varies from $70 \%-80 \%$ in crumb and $20 \%-30 \%$ in crust; this may be caused by a poor bread making technique and an inadequate oven temperature whereby the starch did not produce a sufficient amount of dextrin [19].

The obtaining of the maximum volume may be due to the release of exopolysaccharides which strengthen the gluten network and the starch, influencing both the size and retrogradation of the product, hence the bread with yeast and lactobacilli had good volume [14].

The plastic and mechanical qualities of the dough are of great importance in breadmaking since they all allow the formation of smaller cells under the pressure of the gas retained by the fine gluten network [14]. If this does not happen, diverse alterations or faults appear as seen in the images of the breads with Lactobacillus. Thus, if the dough is too solid, the gas is not distributed evenly throughout, causing deep or less deep cracks to form in the crust or crumb which are ports of entry for microorganisms, such as fungi [20]. A frequent fault is also the formation of moist striations under the crust due to the lack of sponginess of the dough. Sometimes during breadmaking there is a partial separation between the crust and crumb, as observed when the dough, rich in gassy bubbles, is placed in the hot oven too soon. This causes the solid crust to form before the gas is released, and the pressure of the gas separates the crust from the crumb. On the other hand, when the gas is released before the

Table 3. The physical tests and texture profile analysis of the bread with Lactobacillus, pulque and yeast.

\begin{tabular}{ccccccccc}
\hline Bread & $\begin{array}{c}\text { Lift } \\
\text { Coefficient }\end{array}$ & $\begin{array}{c}\text { Specific } \\
\text { Volume } \\
\left(\mathrm{cm}^{3} / \mathrm{g}\right)\end{array}$ & \% Crust & \% Crumb & $\begin{array}{c}\text { Hardness } \\
(\mathrm{g})\end{array}$ & $\begin{array}{c}\text { Adhesiveness } \\
(\mathrm{g} * \mathrm{~s})(-)\end{array}$ & $\begin{array}{c}\text { Elasticity } \\
(\mathrm{mm})\end{array}$ & $\begin{array}{c}\text { Cohesiveness } \\
(\mathrm{g} * \mathrm{~s})\end{array}$ \\
\hline LB7 & $2.611 \pm 0.02^{\mathrm{a}}$ & $0.52 \pm 0.00^{\mathrm{a}}$ & $18.49 \pm 0.84^{\mathrm{b}}$ & $81.51 \pm 0.84^{\mathrm{a}}$ & $256.70 \pm 0.06^{\mathrm{d}}$ & $0.00 \pm 0.00^{\mathrm{a}}$ & $0.742 \pm 0.01^{\mathrm{ab}}$ & $0.283 \pm 0.13^{\mathrm{a}}$ \\
LB6 & $2.571 \pm 0.03^{\mathrm{a}}$ & $0.45 \pm 0.00^{\mathrm{b}}$ & $18.00 \pm 1.12^{\mathrm{b}}$ & $82.00 \pm 1.12^{\mathrm{a}}$ & $412.58 \pm 0.21^{\mathrm{b}}$ & $0.00 \pm 0.00^{\mathrm{a}}$ & $0.785 \pm 0.04^{\mathrm{ab}}$ & $0.289 \pm 0.01^{\mathrm{a}}$ \\
LB2 & $2.314 \pm 0.34^{\mathrm{a}}$ & $0.46 \pm 0.01^{\mathrm{b}}$ & $18.91 \pm 0.66^{\mathrm{b}}$ & $81.09 \pm 0.66^{\mathrm{a}}$ & $175.46 \pm 0.35^{\mathrm{e}}$ & $0.00 \pm 0.00^{\mathrm{a}}$ & $0.665 \pm 0.12^{\mathrm{ab}}$ & $0.266 \pm 0.01^{\mathrm{a}}$ \\
Pulque & $1.972 \pm 0.00^{\mathrm{b}}$ & $0.45 \pm 0.01^{\mathrm{b}}$ & $16.97 \pm 0.87^{\mathrm{b}}$ & $83.03 \pm 0.87^{\mathrm{a}}$ & $422.43 \pm 0.38^{\mathrm{a}}$ & $0.26 \pm 0.11^{\mathrm{a}}$ & $0.776 \pm 0.00^{\mathrm{ab}}$ & $0.337 \pm 0.03^{\mathrm{a}}$ \\
LB2Y & $1.503 \pm 0.01^{\mathrm{c}}$ & $0.21 \pm 0.00^{\mathrm{c}}$ & $30.15 \pm 1.04^{\mathrm{a}}$ & $69.85 \pm 1.04^{\mathrm{b}}$ & $46.40 \pm 0.39^{\mathrm{f}}$ & $170.97 \pm 0.80^{\mathrm{c}}$ & $0.517 \pm 0.01^{\mathrm{b}}$ & $0.220 \pm 0.08^{\mathrm{a}}$ \\
LB6Y & $1.501 \pm 0.01^{\mathrm{c}}$ & $0.22 \pm 0.02^{\mathrm{c}}$ & $29.33 \pm 0.07^{\mathrm{a}}$ & $70.67 \pm 0.07^{\mathrm{b}}$ & $46.40 \pm 0.40^{\mathrm{f}}$ & $0.10 \pm 0.12^{\mathrm{a}}$ & $0.615 \pm 0.16^{\mathrm{ab}}$ & $0.202 \pm 0.07^{\mathrm{a}}$ \\
LB7Y & $1.488 \pm 0.01^{\mathrm{c}}$ & $0.22 \pm 0.02^{\mathrm{c}}$ & $29.07 \pm 0.86^{\mathrm{a}}$ & $70.93 \pm 0.86^{\mathrm{b}}$ & $47.18 \pm 0.58^{\mathrm{f}}$ & $13.94 \pm 0.03^{\mathrm{b}}$ & $0.858 \pm 0.03^{\mathrm{a}}$ & $0.264 \pm 0.04^{\mathrm{a}}$ \\
Baker’s & $1.487 \pm 0.00^{\mathrm{c}}$ & $0.21 \pm 0.01^{\mathrm{c}}$ & $30.65 \pm 0.68^{\mathrm{a}}$ & $69.35 \pm 0.68^{\mathrm{b}}$ & $373.95 \pm 0.57^{\mathrm{c}}$ & $0.61 \pm 0.45^{\mathrm{a}}$ & $0.575 \pm 0.33^{\mathrm{ab}}$ & $0.285 \pm 0.08^{\mathrm{a}}$ \\
Yeast & & & & & & & &
\end{tabular}

${ }^{\mathrm{a}}$ Means in the column with a different letter are significantly different according to the Tukey test $(\mathrm{P}<0.05)$. LB7 = Lactobacillus paracasei ssp. paracasei; LB6 = Lactobacillus paracasei ssp. paracasei; LB2 = Lactobacillus paracasei ssp. paracasei; LB7Y = Lactobacillus paracasei ssp. paracasei + yeast; LB6Y = Lactobacillus paracasei ssp. paracasei + yeast; LB2Y = Lactobacillus paracasei ssp. paracasei + yeast. 
crust is formed by not being placed in the very hot oven, a flat bread is produced [21] [22], reported that the bread samples with Lactobacillus was the highest for the control $\left(303.9 \mathrm{~cm}^{3}\right)$ this it is not coincide whit this investigation, the results obtained were smaller $\left(210.0 \mathrm{~cm}^{3}\right)$. The sample LB7 was of $520 \mathrm{~cm}^{3}$, value more high that the reported for this author. The pulque's bread too was high $\left(540 \mathrm{~cm}^{3}\right)$. The differences can be must to the process and formulations different.

\subsection{Texture Profile Analysis of the Bread}

Table 3 shows the hardness results where all the breads are significantly different. This results match with the reported for Eliasson and Larsson [23]. The pulque bread required the most force to compress. While there was no adhesiveness in the breads inoculated with lactobacilli, there was in those inoculated with added yeast, LB2 plus yeast needing more effort to remove the probe which is equivalent to the human palate. The elasticity of the bread with LB2 and LB6 is different while in the bread with LB7 and pulqueit is the same. The cohesiveness of the 4 samples is different in the bread with LB6 and LB7 but not so in the bread with pulque and LB2. The breadcrumb should recover quickly after being pressed and not be too spongy or resume its shape too slowly. The degree of elasticity in the crumb is important in determining the ease with which butter can be spread over it, above all when hard [24]. In this study the hardness was highest that the reported for Gul et al. [22] it could be for the differents formulations and process of elaboration for the bread. Researchers reported that LAB increased shelf life of bread and delayed staling. The hardness in this study decreased with differents samples. A great improvement of textural properties of bread added with commercial and microorganism derived emulsifiers. The emulsifiers addition enhanced bread specific volume and improved bread appearance, textural properties of breads [25]. In the Table 4, it showed the bread's color, the yellow coloration decreases with respect to the kind of LAB that is added.

\subsection{Bread Structure Analysis}

The breads made with lactobacilli plus yeast had a finer crumb, predominantly with a cell size less than $1 \mathrm{~mm}^{2}$ (Table 4) in higher proportion to the breads made only with lactobacilli; in these latter breads large holes were found that were considered defects. The consumers chose in the bread preference for porous appearance and floury odor, this parameter is better in LB6 + L, LB2 + L and LB7 + L in comparison whit the Yeast [23]. The cell density results for different kind of commercial sweet breads evaluated by the two different there holding methods and classified by different cell areas [26]. The differences among bread crumb structures were also detected, showing that pound cake bread had the largest number of cells per unit area as compared to the other samples. This difference may be a consequence of the bread making process and the ingredients used, such as fat, sugar, additives or others. The three kinds of sweet commercial breads presented different cells areas depending on the range of objects used to evaluate them. When all cells were considered, there were not significant differences in the mean cell areas of Danish and yeast sweet bread samples, while in all other cases, there were significant variations.

Table 4. Color and crumb structure analysis of bread with Lactobacillus, pulque and yeast.

\begin{tabular}{ccccccccc}
\hline Bread & $\mathrm{L}$ & $\mathrm{a}$ & $\mathrm{b}$ & Cells (No.) & $\begin{array}{c}\text { Cells/total } \\
\text { area }\end{array}$ & $\begin{array}{c}\text { Cell/cm } \\
{ }^{2}\end{array}$ & $\begin{array}{c}\text { Cell size } \\
\left(\mathrm{mm}^{2}\right)\end{array}$ & $\begin{array}{c}\text { Uniformity } \\
\left(\mathrm{mm}^{2}\right)\end{array}$ \\
\hline LB6 + Y & $757 \pm 6.81^{\mathrm{a}}$ & $0.177 \pm 0.01^{\mathrm{e}}$ & $10.33 \pm 3.06^{\mathrm{a}}$ & $757 \pm 6.81^{\mathrm{a}}$ & $0.177 \pm 0.01^{\mathrm{e}}$ & $10.33 \pm 3.06^{\mathrm{a}}$ & $3.9 \pm 0.00^{\mathrm{a}}$ & $98.19 \pm 1.32^{\mathrm{a}}$ \\
LB2 + Y & $491 \pm 6.66^{\mathrm{b}}$ & $0.241 \pm 0.00^{\mathrm{d}}$ & $8.00 \pm 4.58^{\mathrm{a}}$ & $491 \pm 6.66^{\mathrm{b}}$ & $0.241 \pm 0.00^{\mathrm{d}}$ & $8.00 \pm 4.58^{\mathrm{a}}$ & $4.2 \pm 0.00^{\mathrm{a}}$ & $96.77 \pm 4.44^{\mathrm{a}}$ \\
LB7 + Y & $385 \pm 3.00^{\mathrm{c}}$ & $0.314 \pm 0.02^{\mathrm{c}}$ & $7.33 \pm 2.31^{\mathrm{a}}$ & $385 \pm 3.00^{\mathrm{c}}$ & $0.314 \pm 0.02^{\mathrm{c}}$ & $7.33 \pm 2.31^{\mathrm{a}}$ & $5.6 \pm 0.03^{\mathrm{a}}$ & $90.40 \pm 7.06^{\mathrm{b}}$ \\
Pulque & $295 \pm 3.00^{\mathrm{d}}$ & $0.200 \pm 0.01^{\mathrm{e}}$ & $10.67 \pm 9.02^{\mathrm{a}}$ & $295 \pm 3.00^{\mathrm{d}}$ & $0.200 \pm 0.01^{\mathrm{e}}$ & $10.67 \pm 9.02^{\mathrm{a}}$ & $4.4 \pm 0.02^{\mathrm{a}}$ & $74.30 \pm 6.97^{\mathrm{c}}$ \\
Yeast & $327 \pm 1.51^{\mathrm{d}}$ & $0.328 \pm 0.64^{\mathrm{c}}$ & $11.3 \pm 1.02^{\mathrm{a}}$ & $327 \pm 1.51^{\mathrm{d}}$ & $0.328 \pm 0.64^{\mathrm{c}}$ & $11.3 \pm 1.02^{\mathrm{a}}$ & $4.4 \pm 0.02^{\mathrm{a}}$ & $59.91 \pm 0.07^{\mathrm{d}}$ \\
LB7 & $177 \pm 2.65^{\mathrm{e}}$ & $0.324 \pm 0.01^{\mathrm{c}}$ & $5.33 \pm 1.15^{\mathrm{a}}$ & $177 \pm 2.65^{\mathrm{e}}$ & $0.324 \pm 0.01^{\mathrm{c}}$ & $5.33 \pm 1.15^{\mathrm{a}}$ & $4.7 \pm 0.01^{\mathrm{a}}$ & $32.65 \pm 2.63^{\mathrm{d}}$ \\
LB2 & $113 \pm 2.08^{\mathrm{f}}$ & $0.451 \pm 0.04^{\mathrm{b}}$ & $5.33 \pm 0.58^{\mathrm{a}}$ & $113 \pm 2.08^{\mathrm{f}}$ & $0.451 \pm 0.04^{\mathrm{b}}$ & $5.33 \pm 0.58^{\mathrm{a}}$ & $5.0 \pm 0.01^{\mathrm{a}}$ & $26.28 \pm 5.72^{\mathrm{d}}$ \\
LB6 & $104 \pm 2.52^{\mathrm{g}}$ & $0.543 \pm 0.02^{\mathrm{a}}$ & $5.67 \pm 2.08^{\mathrm{a}}$ & $104 \pm 2.52^{\mathrm{g}}$ & $0.543 \pm 0.02^{\mathrm{a}}$ & $5.67 \pm 2.08^{\mathrm{a}}$ & $6.9 \pm 0.03^{\mathrm{a}}$ & $17.51 \pm 1.21^{\mathrm{e}}$ \\
\hline
\end{tabular}

${ }^{\mathrm{a}}$ Means in the column with a different letter are significantly different according to the Tukey test $(\mathrm{P}<0.05)$. LB7 = Lactobacillus paracasei ssp. $p a-$ racasei; LB6 = Lactobacillus paracasei ssp. paracasei; LB2 = Lactobacillus paracasei ssp. paracasei; LB7 + Y = Lactobacillus paracasei ssp. paracasei + yeast; LB6 + Y = Lactobacillus paracasei ssp. paracasei + yeast; LB2 + Y = Lactobacillus paracasei ssp. paracasei + yeast. 
Table 5. Sensory analysis of the different breads with Lactobacillus, pulque and yeast.

\begin{tabular}{cccccc}
\hline BREAD & Sponginess & Aroma & Flavor & Color & Acceptability \\
\hline LB2 + Y & $4.5 \pm 0.51^{\mathrm{a}}$ & $4.06 \pm 0.87^{\mathrm{b}}$ & $4.52 \pm 0.79^{\mathrm{b}}$ & $4.00 \pm 0.83^{\mathrm{a}}$ & $4.020 \pm 0.68^{\mathrm{b}}$ \\
LB6 + Y & $4.44 \pm 0.70^{\mathrm{a}}$ & $4.44 \pm 0.73^{\mathrm{a}}$ & $4.64 \pm 0.97^{\mathrm{b}}$ & $3.22 \pm 0.99^{\mathrm{b}}$ & $4.14 \pm 0.65^{\mathrm{b}}$ \\
LB7 + Y & $4.38 \pm 0.60^{\mathrm{a}}$ & $4.36 \pm 0.83^{\mathrm{ab}}$ & $4.66 \pm 1.02^{\mathrm{b}}$ & $3.26 \pm 1.24^{\mathrm{b}}$ & $4.16 \pm 0.76^{\mathrm{b}}$ \\
Yeast & $4.35 \pm 0.18^{\mathrm{a}}$ & $4.32 \pm 0.65^{\mathrm{ab}}$ & $4.57 \pm 0.78^{\mathrm{b}}$ & $3.32 \pm 0.87^{\mathrm{b}}$ & $4.11 \pm 0.63^{\mathrm{b}}$ \\
Pulque & $1.76 \pm 0.23^{\mathrm{b}}$ & $4.32 \pm 0.32^{\mathrm{ab}}$ & $4.87 \pm 0.65^{\mathrm{a}}$ & $3.12 \pm 0.87^{\mathrm{b}}$ & $4.98 \pm 0.56^{\mathrm{a}}$ \\
LB7 & $1.84 \pm 0.68^{\mathrm{b}}$ & $4.22 \pm 0.86^{\mathrm{ab}}$ & $4.84 \pm 0.70^{\mathrm{a}}$ & $3.24 \pm 1.20^{\mathrm{b}}$ & $4.86 \pm 0.75^{\mathrm{a}}$ \\
LB2 & $1.82 \pm 0.77^{\mathrm{b}}$ & $4.48 \pm 0.68^{\mathrm{a}}$ & $4.96 \pm 1.05^{\mathrm{a}}$ & $2.36 \pm 0.87^{\mathrm{c}}$ & $4.96 \pm 1.18^{\mathrm{a}}$ \\
LB6 & $1.58 \pm 0.50^{\mathrm{b}}$ & $3.68 \pm 0.94^{\mathrm{c}}$ & $4.90 \pm 1.01^{\mathrm{a}}$ & $3.16 \pm 1.13^{\mathrm{b}}$ & $4.90 \pm 0.65^{\mathrm{a}}$ \\
\hline
\end{tabular}

${ }^{\mathrm{a}}$ Means in the column with a different letter are significantly different according to the Tukey test $(\mathrm{P}<0.05)$. LB7 = Lactobacillus paracasei ssp. paracasei; LB6 = Lactobacillus paracasei ssp. paracasei; LB2 = Lactobacillus paracasei ssp. paracasei; LB7Y = Lactobacillus paracasei ssp. paracasei + yeast; LB6Y = Lactobacillus paracasei ssp. paracasei + yeast; LB2Y = Lactobacillus paracasei ssp. paracasei + yeast.

\subsection{Sensory Analysis of the Bread}

Table 5 shows the results of the sensory evaluation of the breads with Lactobacillus compared to those inoculated with Lactobacillus plus yeast. All the breads inoculated only with Lactobacillus were equal in terms of sponginess having the minimum scale values; however, when the baker's yeast was added their sponginess was of the highest values. Bread with Lactobacillus was the best accepted among the judges in spite of its sponginess not being statistically the best. The organoleptic attributes of the bread the best in terms organoleptic properties was with $L b$. sake and S. cereviciae [22]. In this study the best formulation was with LB7, LB2 and LB6 for that results it is not coincide [22] [27]. But these results are similar whit Martinez [1] reported that Lb. plantarum and $L b$. brevis affected positively the sensory properties of sourdoughs breads.

\section{Conclusion}

According to the results obtained and consulted from the bibliography, the best result from the fermentation of the doughs was the LB7 + yeast mixture and this was similar in breadmaking.

\section{Acknowledgements}

The authors acknowledge PIFI-SEP for financial support. The student Ma. Guadalupe Alvarado Resendiz wishes to thank the CONACYT for financial her scholarship.

\section{References}

[1] Martínez-Anaya, M.A. (2003) Associations and Interactions of Microrganisms in Dough Fermentations. In: Kulp, K. and Lorenz, K., Eds., Effects on Dough and Bread Characteristics. Handbook of Dough fermentations, Marcel Dekker, Inc., New York, Vol. 1, 63-95.

[2] De Vuyst, L.V., Schrijvers, S., Paramithiotis, B., Hoste, M., Vancanneyt, J., Swings, G., Kalantzopoulos, E., Tsakalidou, E. and Messens, W. (2002) The Bioversity of Lactic Acid Bacteria in Greek Traditional Wheat Sourdoughs Is Reflected in Both Composition and Metabolite Formation. Applied and Environmental Microbiology, 68, 6059-6069.

[3] Corsetti, A., Gobetti, M., Baliestrieri, F., Paoletti, F., Russi, L. and Rossi, J. (1998) Sourdough Lactic Acid Bacteria Effects on Bread Firmness and Staling. Journal of Food Science, 63, 347-351.

[4] Corsetti, A., Gobetti, M., Rossi, J. and Damiami, P. (1998) Antimould Activity of Sourdough Lactic Acid Bacteria: Identification of a Mixture of Organic Acids Produced by Lactobacillus sanfrancisco CB1. Applied Microbiology and Biotechnology, 50, 253-256.

[5] Hervè, R., Valèrie, G., Dominique, L., Philippe, R., Yves, V. and Fontagnè, F.C. (2006) Study of the Behaviour of Lactobacilus plantarum and Leuconostoc Starters during a Complete Wheat Sourdough Breadmaking Process. Journal of Food Science and Technology, 39, 256-265.

[6] Steinkraus, K.H. (1996) Handbook of Indigenous Fermented Foods. Marcel Dekker, New York, 52-72.

[7] Sánchez, I., Palop, L.L. and Ballesteros, C. (2000) Biochemical Characterization of Lactic Acid Bacteria Isolated from Spontaneous Fermentation of “Almagro” Eggplants. International Journal of Food Microbiology, 59, 9-17. 
http://dx.doi.org/10.1016/S0168-1605(00)00256-7

[8] AACC (1995) Approved Method of the AACC. 9th Edition, American Association of Cereal Chemists, St. Paul.

[9] AOAC (1999) Official Method of Analysis of AOAC Intl. 16th Edition, Association of Official Analytical Chemists, Maryland.

[10] Herreros, M.A., Arenas, R., Sandoval, M.H., Castro, J.M., Fresno, J.M. and Tornadijo, M.E. (2006) Effect of Addition of Native Cultures on Characteristics of Armada Cheese Manufactured Whit Pasteurized Milk: A Preliminary Study. International Dairy Journal, 26, 220-227.

[11] Saeed, M. (2011) Isolation Characterization and Utilization of Starter Culture for the Production of Sourdough Bread. Ph.D. Dissertation, National Institute of Food Science and Technology University of Agriculture, Faisalabad. http://prr.hec.gov.pk/Thesis/134S.pdf

[12] Gêlinas, O., Roy, G. and Guillet, M. (1999) Relative Effects of Ingredients on Cake Staling Based on an Accelerated Shelf-Live Test. Journal of Food Science, 64, 937-940.

[13] Anzaldúa, M.A. (1994) La Evaluación Sensorial de los Alimentos en la teoría y la Práctica. Editorial Acribia, Zaragoza España, 67-113.

[14] Goesaert, H., Bris, K., Veraberbeke, W.S., Courtin, C.M., Gebruers, K. and Delcour, J.A. (2005) Wheat Flour Constituents: How They Impact Bread Quality and How to Impact Their Functionality. Trends in Food Science and Technology, 16, 12-13. http://dx.doi.org/10.1016/j.tifs.2004.02.011

[15] Pinal, L., Cornejo, E. and Arellano, M. (2009) Effect of Agave Tequilana Age, Cultivation Field Location and Yeast Strain on Tequila Fermentation Process. Journal of Industrial Microbiology and Biotechnology, 36, 655-661.

[16] Chung, H.C., Young, J. and Dong, H. (2012) Optimum Conditions for Combined Application of Leuconostoc sp. and Saccharomyces sp. to Sourdough. Food Science and Biotechnology, 11, 1373-1379.

[17] Corsetti, A., Settanni, L., Van Sinderen, D., Felis, G.E., Dellaglio, F. and Gobbetti, M. (2005) Lactobacillus rossii sp. Nov. Isolated from Wheat Sourdough. International Journal of Systematic and Evolutionary Microbiology, 55, 35-40.

[18] Moreia, R., Chenlo, F., Torres, M. and Prieto, M.D. (2012) Technological Assessment of Chesnut Flour Doughs Regarding to Doughs from Other Commercial Flours and Formulations. Food and Bioprocess Technology, 5, 2301-2310.

[19] Esteller, M.S., Amaral, R.L. and Lannes, S.C. (2004) Effect of Sugar and Fat Replacers on the Texture of Baked Goods. Journal of Texture Studies, 35, 383-339.

[20] Sánchez, M.E., Ortíz, A., Mora, R., Chanona, J. and Necoechea, H. (2008) Comparison of Crumb Microstructure from Pound Cakes Baked in a Microwave or Conventional Oven. Journal of Food Science and Technology, 41, 620-627.

[21] Dendy, D.A. and Dobraszczyk, B.J. (2004) Cereales y Productos Derivados. Química y Tecnología. Editorial Acribia, Zaragoza, 223-278.

[22] Gul, H., Ôzcelik, S., Sagdic, O. and Certel, M. (2005) Sourdough Bread Production with Lactobacilli and S. cerevisiae Isolated from Sourdough. Process Biochemistry, 40, 691-697.

[23] Eliasson, A.C. and Larsson, K. (1993) Cereals in Bread Making. Marcel Dekker, New York, 332-334.

[24] Zghal, M., Scanlon, M. and Sapirstein, H. (2001) Effect of Flour Strength, Baking Absorption and Processing Conditions on the Structure and Mechanical Properties of Bread Crumb. Cereal Chemistry, 78, 1-7. http://dx.doi.org/10.1094/CCHEM.2001.78.1.1

[25] Mnif, I., Besbes, S., Ellouze, R., Ellouze-Chaabouni, S. and Ghribi, D. (2012) Improvement of Bread Quality and Bread Shelf-Life by Bacillus subtilis Biosurfactant Addition. Food Science and Biotechnology, 21, 1105-1112.

[26] Farrera, R.R., Salgado C.M., Chanona, J., Gutiérrez, G.F., Alamilla, L. and Calderon, G. (2012) Evaluation of Image Analysis Tools for Characterization of Sweet Bread Crumb Structure. Food and Bioprocess Technology, 5, 474-484.

[27] Escalante, A., Giles, G.M., Hernández, G., Córdova, A., López, M.A., Goset, G. and Bolivar, F. (2008) Analysis of Bacterial Community during the Fermentation of Pulque a Traditional Mexican Alcoholic Beverage, Using a Polyphasic Approach. International Journal of Food Microbiology, 2, 126-134. 
Scientific Research Publishing (SCIRP) is one of the largest Open Access journal publishers. It is currently publishing more than 200 open access, online, peer-reviewed journals covering a wide range of academic disciplines. SCIRP serves the worldwide academic communities and contributes to the progress and application of science with its publication.

Other selected journals from SCIRP are listed as below. Submit your manuscript to us via either submit@scirp.org or Online Submission Portal.
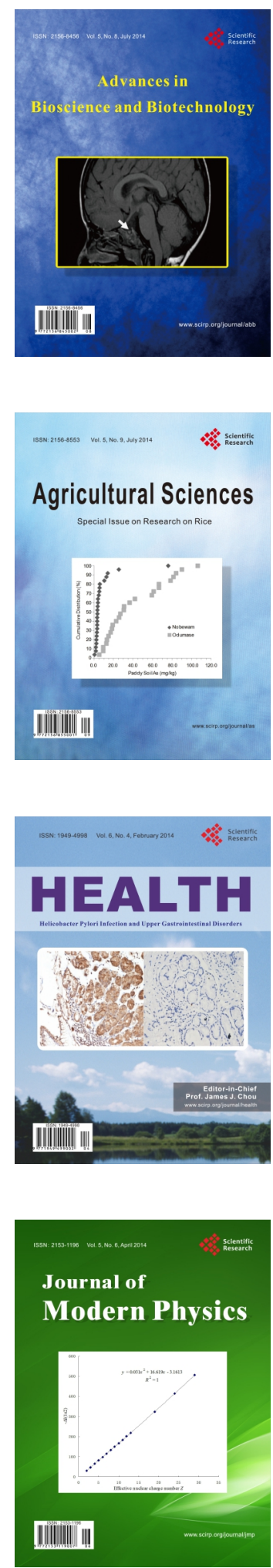
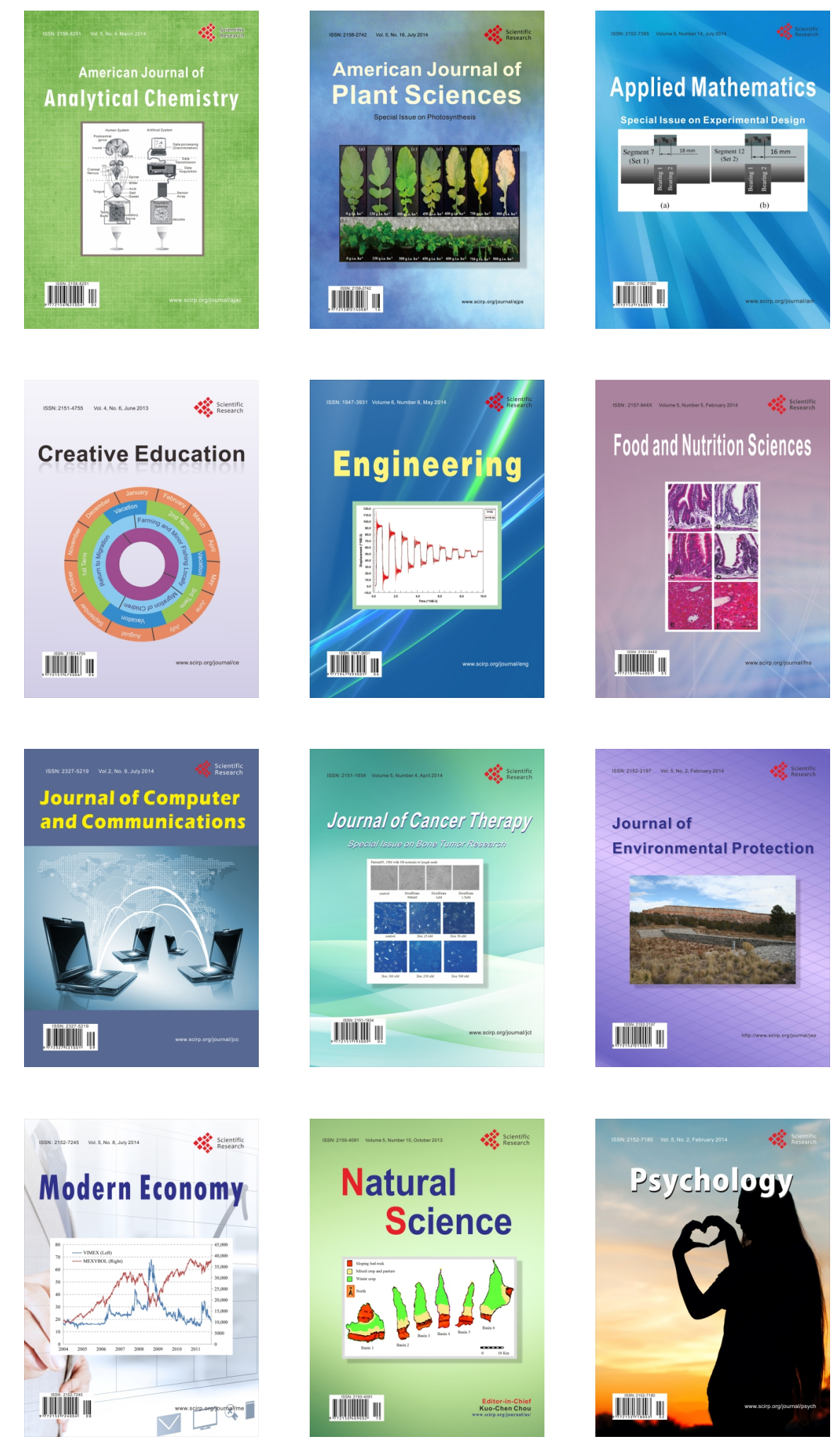